\title{
Istanbul: the challenges of integrated water resources management in Europa's megacity
}

\author{
Kees van Leeuwen • Rosa Sjerps
}

Received: 22 October 2014/Accepted: 10 February 2015/Published online: 20 February 2015

(C) The Author(s) 2015. This article is published with open access at Springerlink.com

\begin{abstract}
Effective integrated water resources management (IWRM) and developments impacting on water resources are recognized as key components of environmentally sustainable development. Istanbul (Turkey) is a very large metropolitan city with a population of approximately 14 million. Istanbul is one of the 23 megacities (metropolitan areas with a population of more than 10 million) in the world and one of the most rapidly growing cities in Europe. The annual population growth is $2.8 \%$. The population growth in the city is almost twice the overall rate of the whole of Turkey, because of a large in-migration. The present study is a baseline assessment of IWRM of Istanbul and also provides a critical review of Istanbul's future challenges. The assessment is part of an action on water governance (City Blueprints) in the context of the European Innovation Partnership on Water of the European Commission. The City Blueprint indicator approach and process have been applied as first step of gaining a better understanding of IWRM and the challenges ahead. This is done by using well-established and high-quality data sets, a relatively cost-effective online survey and a relatively simple questionnaire. Istanbul has set a good example to the challenges faced in water supply in megacities, where illegal settlements on watershed zones posed a threat to scarce water resources. Despite these enormous efforts, the projected future population growth and climate change in Istanbul will necessitate further major transitions towards sustainable IWRM. This holds for all aspects of the water cycle: water quality, water quantity, water supply and sanitation, coping with extreme weather events (floods and droughts), as well as for the protection of the sources of water, i.e. ecosystem conservation. Istanbul is a place where problems emerge and solutions need to be found. The time window available to do this is rapidly closing. As such, this review of IWRM of Istanbul confirms the conclusions of the World Economic Forum that water
\end{abstract}

K. van Leeuwen $(\bowtie) \cdot R$. Sjerps

KWR Watercycle Research Institute, Groningenhaven 7, 3433 PE Nieuwegein, The Netherlands e-mail: Kees.van.Leeuwen@kwrwater.nl

URL: http://www.kwrwater.nl

K. van Leeuwen

Copernicus Institute for Sustainable Development and Innovation, Utrecht University, Heidelberglaan

2, 3584 CS Utrecht, The Netherlands 
supply is one of the top three global risks for both the impact and likelihood. Our framework has been applied for nearly 40 cities, and the results for Istanbul are discussed in the broader context of recent initiatives on water governance and smart cities by the European Commission.

Keywords IWRM - Water governance $\cdot$ Water scarcity $\cdot$ City Blueprint ${ }^{\circledR} \cdot$ Blue City Index ${ }^{\circledR}$

\section{Introduction}

Cities are home to many. There are currently more than 400 cities with more than 1 million inhabitants and 23 megacities (metropolitan areas with a population of more than 10 million) mainly in Asia (UN 2012). According to the United Nations (UN), $50 \%$ of people live in cities and by 2050, this will be $67 \%$ (UN 2012). In developed countries, this percentage is even higher (more than $86 \%$ ). Global urbanization is taking place at an unparalleled speed. In 1970, there were just two megacities (Tokyo and New York); in 1990, there were ten; in 2011, 23; and by 2025, there will be 37 megacities. Istanbul is one of the 23 megacities on this globe. The UN estimates that between 2011 and 2050, the world population will grow from 7 to 9.3 billion and that the population in cities will increase from 3.6 to 6.3 billion, while the number of people living in rural areas will decline. This means that the growth in the world population will be absorbed by the cities. Together with the migration from rural areas to the cities, during this period more than 200,000 people - a day-will need to find a new place to live in an urban environment. This will be accompanied by strong growth in urban water demands, especially in East and West Africa, Latin America and Asia (Dobbs et al. 2011, 2012).

The availability of sufficient clean and freshwater is a prerequisite for the health, economic development and social well-being of any society. The world's water resources are threatened, however, by increasing demand from growing urban populations leading to groundwater depletion, salt water intrusion, and the deterioration of water quality from pollution and climate change (Hoekstra and Wiedman 2014; Huynen et al. 2013; Van Leeuwen 2013). These threats are placing water increasingly higher on the international agenda. Recently, the World Economic Forum (2014) ranked the ten global risks of highest concern. Four of them are related to water: the food crisis (rank 8), as agriculture accounts to $70 \%$ of the global water use (UN 2014); the greater incidence of extreme weather events (rank 6); failure of climate change mitigation and adaptation (rank 5); and the water crises (rank 3). The United Nations estimates that in 2025 approximately 2 billion people will have an absolute water shortage and that two-thirds of the world population will be affected by water scarcity (UN 2012). Because of the rapid urbanization, cities are the main problem holders (Grimm et al. 2008; Engel et al. 2011; EEA 2012).

Situated where Asia and Europe meet, Istanbul (the largest city in Turkey) has been a city at the centre of life, art and culture for thousands of years. It is a very large metropolitan city with a population of 13.9 million (Turkish Statistical Institute 2013). The city is located in the north-western region of Turkey and has Asian and European parts in the sides of the Bosphorus strait. This waterway connects the Sea of Marmara and the Black sea. The city forms the largest urban agglomeration in Europe and is classified as a megacity (a city with a population over 10 million people). Furthermore, Istanbul is one of 
the most rapidly growing cities in Europe. The annual population growth is $2.8 \%$. The population grew at almost twice the overall rate of the whole of Turkey, because of a large in-migration (Baban et al. 2011; Altinbilek 2006). Hence, water supply and sanitation are of particular concern. The majority of resources are located on the Asian side in contrast to the urban density. Therefore, the water reservoirs are linked, and an integrated system is used with operational flexibility. Furthermore, water from adjacent catchment areas is connected to secure water supply for the city at high cost (ISKI 2013).

Istanbul has always faced water scarcity in its history due to its distant location to drinking water resources (Saatci 2013). The city kept growing, and the need for water increased accordingly (Baban et al. 2011). In recent years, Istanbul has been suffering from drought, especially in 2006, with the lowest rainfall being recorded in the last 50 years (ISKI 2013). It is estimated that the frequency of extreme events, such as droughts and intense rainfalls, will be increased due to the climate change. It is expected that one of the main impacts of climate change will be water scarcity in the Mediterranean Region. Therefore, effective strategies and adaptation plans have been developed including water saving campaigns, transfer of water from adjacent basins and reuse of treated wastewater (Baban et al. 2011; ISKI 2013).

The present study provides a baseline assessment of integrated water resources management (IWRM) of Istanbul as case study of the Mediterranean area. It is part of an action on water governance by the City Blueprint Action Group in the context of European Innovation Partnership on Water of the European Commission (European Commission 2014). Until now, nearly 40 cities have been assessed and the results for 30 cities have been published as interim report on the website of the City Blueprint Action Group (Van Leeuwen and Sjerps 2014; European Commission 2014). Istanbul is the only megacity (a city with more than 10 million inhabitants) assessed so far, and its performance on IWRM is critically analysed and so are its future challenges on environmental management.

\section{Methodology}

A set of indicators, i.e. the City Blueprint ${ }^{\circledR}$, has been developed to assess the sustainability of IWRM. The City Blueprint comprises a set of 24 dedicated indicators divided over eight categories, i.e. water security, water quality, drinking water, sanitation, infrastructure, climate robustness, biodiversity and attractiveness and governance including public participation (Van Leeuwen et al. 2012). The indicators are scored on a scale between 0 (very poor performance) to 10 (excellent performance). General information about the indicators, sources of information and limitations of the City Blueprint approach are provided by Van Leeuwen and Chandy (2013) and Van Leeuwen (2013). The methodology is shortly summarized in Table 1. Detailed information about the 24 indicators, the data sources, the scoring methods and sample calculations for each of the 24 indicators an extensive City Blueprint questionnaire is provided on the website of the European Innovation Partnership on Water (European Commission 2014). A critical discussion about the strength and limitations of the City Blueprint methodology is also provided in Van Leeuwen (2013).

The City Blueprint ${ }^{\circledR}$ covers a broad range of aspects and can be used as a first step to benchmark IWRM in cities (Philip et al. 2011; Van Leeuwen and Chandy 2013). It is a baseline assessment and part of a strategic planning process and provides the framework that facilitates the shift to more integrated policies, governance structures, practices and choice of technology for more sustainable water management (Fig. 1; Philip et al. 2011; Brown et al. 2009). More specifically, the City Blueprint can be applied: (1) to 
Table 1 Short summary of the City Blueprint method

\begin{tabular}{ll}
\hline Goal & Baseline assessment of the sustainability of IWRM \\
Indicators & Twenty-four indicators divided over eight broad categories: \\
& 1. Water security \\
& 2. Water quality \\
& 3. Drinking water \\
& 4. Sanitation \\
& 5. Infrastructure \\
& 6. Climate robustness \\
& 7. Biodiversity and attractiveness \\
& 8. Governance \\
Data & Public data or data provided by the (waste) water utilities and cities based on a questionnaire \\
for IWRM & 0 (concern) to 10 (no concern) \\
Scores & Blue City Index ${ }^{\circledR}$, the arithmetic mean of 24 indicators which varies from 0 to 10 \\
BCI & Water utility, water board, city council, companies, NGOs, etc. \\
Stakeholders & Interactive with all stakeholders involved early on in the process \\
Process &
\end{tabular}

communicate a city's IWRM performance and exchange experiences, (2) to select appropriate water supply and sanitation strategies and (3) to develop technological and non-technological options as future alternatives for the water cycle, where several possible changes in the use of technology, space and socio-economic scenarios can be introduced. This should finally lead to: (4) a selection of measures, including an evaluation of their costs and benefits under different development scenarios, and how to integrate these in long-term planning on urban investments.

The collection of information for Istanbul was carried out by the authors. Feedback was asked from several stakeholders (representatives of municipalities, water utilities, wastewater utilities and water boards) on the preliminary assessment. A site visit was made to Istanbul to drinking water production and wastewater treatment facilities as well as to the bioremediation site in the Golden Horn of Istanbul (Altinbilek 2006). Final reporting was done in an interactive manner with the stakeholders.

The overall score of the sustainability of IWRM of the city is expressed as Blue City Index $(\mathrm{BCI})$. The $\mathrm{BCI}$ is the arithmetic mean of the 24 indicators comprising the City

Fig. 1 Function of the City Blueprint (red box) in the strategic planning process for IWRM according to SWITCH (Philip et al. 2011)

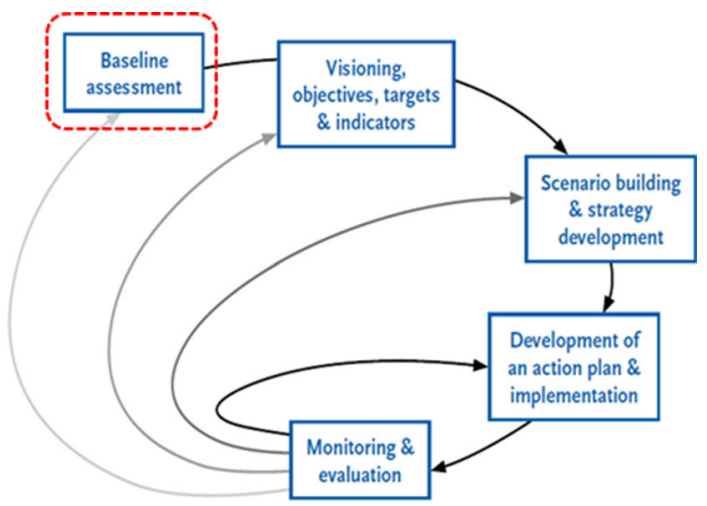


Blueprint and has a theoretical minimum and maximum of 0 and 10 , respectively (Table 1).

\section{Results}

\subsection{Water resources of Istanbul}

Trend analysis of temperature, precipitation, natural stream flow and evapotranspiration for the last 50 years showed that Istanbul has become warmer and drier (Sen 2010). Also, it was found that changes in precipitation or temperature could incur significant impact on the frequency and amount of hydrologic extremes like floods and droughts. Basic information from a variety of sources is summarized in Table 2.

The annual rainfall in Istanbul is $734 \mathrm{~mm}$ (ISKI 2013) and is considerably higher than the average for Turkey (Table 2). Water supply and sanitation are the responsibilities of the public utility Istanbul Su ve Kanalizasyon Idaresi (ISKI) or Istanbul Water Works and Sewerage Administration (IWWS) created in 1981. Information on water and wastewater services has been reported by Altinbilek (2006), Baban et al. (2011), Patan (2012) and ISKI (2013). According to Patan (2012), Istanbul supplies 1353 million $\mathrm{m}^{3} /$ year water mainly from surface water reservoirs. Use of groundwater is not common, constituting only a small fraction of the overall consumption, compared to the other sources. Groundwater accounts for approximately 30 million $\mathrm{m}^{3} /$ year (Baban et al. 2011). Uncontrolled settlement and over-abstraction have diminished groundwater levels and led to salt water intrusion in coastal areas. The decline in the water table due to unsustainable abstraction ranges from $30 \mathrm{~m}$ to as much as $150 \mathrm{~m}$ in some areas (WaterWiki 2015). Surface water, more than $97 \%$ of all of Istanbul's drinking water, is collected in six drinking water reservoirs. Several reservoirs are located on the European side (Terkos, Alibeyköy, Büyükçekmece, Sazlıdere Reservoirs and Istıranca Rivers) and three on the Asian side (Omerli, Darlik and Elmari reservoirs). The water systems consist of dams, reservoirs, water treatment plants and pipelines. Key figures for Istanbul's water infrastructure are given in Table 3.

Currently there are 15 dams with 17,808-km water network in Istanbul (ISKI 2013; Patan 2012; Bekiroglu and Eker 2011). One of the most important water resources of

Table 2 Basic data for Istanbul and Turkey

\begin{tabular}{ll}
\hline Resident population (million) of Istanbul $^{\mathrm{a}}$ & 13.9 \\
Household occupancy of Istanbul ${ }^{\mathrm{b}}$ & 3.9 \\
Annual average rainfall (mm) in Turkey & 593 \\
Daily average air temperature $\left({ }^{\circ} \mathrm{C}\right)$ of Istanbul ${ }^{\mathrm{d}}$ & 15.0 \\
Population density Turkey (inhabitants $\left./ \mathrm{km}^{2}\right)^{\mathrm{c}}$ & 98 \\
Population density Istanbul (inhabitants $\left./ \mathrm{km}^{2}\right)^{\mathrm{a}}$ & 2666 \\
Total renewable water resources per capita $\left(\mathrm{m}^{3} /\right.$ year) in Turkey & 2860 \\
Total freshwater withdrawal as \% of the annual renewable water resources in Turkey & 18.9 \\
\hline a Turkish Statistical Institute (2013) & \\
b Saatci and Akpinar (2007) & \\
c FAO (2014) & \\
d Turkish State Meteorological Service (2013) &
\end{tabular}


Istanbul province is Ömerli Watershed (at the Asian side), which provides about $32 \%$ of the total freshwater supply (Baban et al. 2011; Tezer et al. 2012). System integration has been applied to provide operation flexibility, and water is pumped from one reservoir to another according to the need of area. The use of groundwater is negligible, constituting only a very small portion of the overall consumption, compared to the other sources (Baban et al. 2011).

The reservoirs are exposed to pollution from settlements without adequate sanitation. Water quality is theoretically controlled by conservation zones around the reservoirs. Regulations in these zones limit construction and industrial activities with increasingly strictness closer to the reservoirs. However, there is little enforcement of these regulations in the face of rapid and often unplanned urbanization (Wikipedia 2013). Nutrient control is necessary as a result of eutrophication. This is a primary issue in the reservoirs and linked to population density and percentage urban land use within the watershed (Baykal et al. 2000).

\subsection{Drinking water}

Access to water supply and sanitation in Turkey is high. The joint monitoring programme for water supply and sanitation (WHO 2013) estimated that the urban population had $100 \%$ access to an improved water source in 2011. In rural areas, where a third of the population lives, $99 \%$ has access to an improved water source. ISKI provides water to Istanbul through 17,808-km drinking water network (ISKI 2013). For Istanbul, the score for indicator six, sufficient to drink, is ten (Table 4).

The water obtained from the reservoirs is treated by filters and chlorination before supply to Istanbul. The treated water meets the criteria for drinking water. Pipelines, however, can cause the distributed water to taste badly as a result of the solution of metals. According to a 2004 survey, $35 \%$ of customers stated that they drink water from the tap, up from only $10 \%$ in 2000. During that period, water quality had improved due to network repairs and the completion of new drinking water treatment plants.

The non-revenue water, as a percentage for total distributed water, for whole Turkey, is $59 \%$ (IBNET 2013). Istanbul has substantially reduced water loss in the distribution network in a successful programme (Altinbilek 2006). The percentage water loss has been

Table 3 Characteristics of Istanbul's water and wastewater system (ISKI 2013; Patan 2012)

\begin{tabular}{ll}
\hline Population served (million) & 13.6 \\
Total area served $\left(\mathrm{km}^{2}\right)$ & 5461 \\
Total number of customers (million) & 5.1 \\
Total length of potable water pipes $(\mathrm{km})$ by the end of 2012 & 17,808 \\
Total length of wastewater pipes $(\mathrm{km})$ by the end of 2012 & 16,454 \\
Annual yield of water resources (million $\left.\mathrm{m}^{3} / \mathrm{year}\right)$ & 1353 \\
Average daily water supply (million $\left.\mathrm{m}^{3} / \mathrm{day}\right)$ & 2.25 \\
Capacity of drinking water treatment plants (million $\left.\mathrm{m}^{3} / \mathrm{day}\right)$ & 4.40 \\
Volume of water reservoirs (million $\mathrm{m}^{3}$ ) & 1.35 \\
Capacity of wastewater treatment plants (million $\left.\mathrm{m}^{3} / \mathrm{day}\right)$ & 3.11 \\
Power consumption by ISKI (million $\mathrm{kwh} / \mathrm{year})$ & 932 \\
Number of staff (31-12-2012) & 7496 \\
Budget 2012 (million $€$ ) & 1312 \\
Investment 2012 (million $€$ ) & 590 \\
\hline
\end{tabular}


Table 4 City Blueprint scores of the city of Istanbul

\begin{tabular}{llcclc}
\hline No. & Indicator & Score & No. & Indicator & Score \\
\hline 1 & Water footprint & 6.3 & 13 & Energy efficiency & 5.0 \\
2 & Water scarcity & 5.2 & 14 & Energy recovery & 1.0 \\
3 & Water self-sufficiency & 7.9 & 15 & Nutrient recovery & 0.0 \\
4 & Surface water quality & 5.8 & 16 & Average age sewer system & 5.0 \\
5 & Groundwater quality & 4.0 & 17 & Infrastructure separation & 7.0 \\
6 & Sufficient to drink & 10.0 & 18 & Climate commitments & 4.0 \\
7 & Water system leakages & 7.6 & 19 & Adaptation strategies & 4.0 \\
8 & Water efficiency & 5.0 & 20 & Climate-robust buildings & 3.0 \\
9 & Drinking water consumption & 8.9 & 21 & Biodiversity & 6.3 \\
10 & Drinking water quality & 9.0 & 22 & Attractiveness & 7.0 \\
11 & Safe sanitation & 9.5 & 23 & Management and action plans & 5.0 \\
12 & Sewage sludge recycling & 0.0 & 24 & Public participation & 0.5 \\
\hline
\end{tabular}

reduced from more than $50 \%$ loss prior to 1994 to $34 \%$ in 2000 by the public utility ISKI. The most recent annual report (ISKI 2013) provides a $24 \%$ water loss ratio. This leads to a score for water leakage of 7.6 (Table 4).

An indication for drinking water consumption can be obtained from Table 5. With an annual supply of 952.5 million $\mathrm{m}^{3}$ and a population size of 13 million, an average annual consumption of $73.24 \mathrm{~m}^{3} /$ person is obtained. This is in line with the annual water consumption per head in Istanbul of $68.63 \mathrm{~m}^{3}$ as reported for Istanbul in the European green city index (2009). The drinking water consumption of $68.63 \mathrm{~m}^{3} /$ cap/day leads to a score of 8.9 (Table 4).

\subsection{Wastewater}

In urban areas in Turkey, $97 \%$ of the population has access to improved sanitation facilities, compared to $75 \%$ in rural areas (WHO 2013). In Istanbul, there are 41 wastewater treatment plants. The quantity of wastewater treated is 1119 million $\mathrm{m}^{3} /$ year. About $73 \%$ of treated wastewater goes through pre-treatment, and $27 \%$ is treated in advanced biological and biological treatment plants. Wastewater reuse is taking place at a very moderate scale with a volume of 750,000 $\mathrm{m}^{3} /$ year (ISKI 2013). The Marmara Sea, which is a semi-enclosed sea, is subject to eutrophication due to low regeneration of water and discharge of significant amounts of land-based pollutants. Therefore, almost all of biologically treated wastewaters having higher effluent quality are discharged to the Marmara

Table 5 Drinking water supply-demand and deficit of Istanbul according to Bekiroglu and Eker (2011)

\begin{tabular}{lllll}
\hline Year & $\begin{array}{l}\text { Population } \\
\text { (million) }\end{array}$ & $\begin{array}{l}\text { Demand } \mathrm{m}^{3} / \\
\text { year (million) }\end{array}$ & $\begin{array}{l}\text { Supply } \mathrm{m}^{3} / \\
\text { year (million) }\end{array}$ & $\begin{array}{l}\text { Supply deficit } \mathrm{m}^{3} / \\
\text { year (million) }\end{array}$ \\
\hline 2005 & 11.3 & 1298.0 & 762.0 & 473.2 \\
2010 & 13.0 & 1635.5 & 952.5 & 682.0 \\
2020 & 16.5 & 1798.5 & 1190.6 & 607.9 \\
2030 & 17.7 & 1929.3 & 1488.3 & 441.0 \\
\hline
\end{tabular}


Sea. The less advanced treated wastewaters are discharged to the Bosphorus Strait towards the Black Sea in the North. The Black Sea has a much greater assimilative capacity than the ecologically more sensitive Marmara Sea (Baban et al. 2011). The effects of wastewater treatment systems discharged into the Bosphorus, the Marmara Sea and the Black Sea are controlled by water quality monitoring (Haci and Askin 2008).

In Istanbul, the share of wastewater treated increased from $9 \%$ in 1993 to $95 \%$ in 2004 (Coleman et al. 2009). Therefore, safe sanitation (indicator 11) has been scored with 9.5. In Istanbul, the total daily volume of wastewater treated is an impressive 3 million $\mathrm{m}^{3}$. Also the total length of the sewers is enormous (Table 3). In principle, the sewer system consists of separate sanitary sewers and storm water drains. However, in reality, there are illegal cross-connections so that untreated wastewater reaches the storm water drains and contributes to the pollution of drinking water reservoirs. Therefore, the score for infrastructure separation (indicator 17) becomes seven (Table 4).

\subsection{Surface water quality}

Considering the geographical status of Istanbul with a sloping topography formed by several hills and valleys, natural landscape forming processes such as soil erosion, sediment mobilizations, transport and deposit of mass movements are potential threats to the drinking water supplies and reservoirs (Uyguner 2009). The Bosphorus has been used as a garbage dumb for centuries. The sea strait is much polluted, and floating rubbish is a common sight alongside many of Istanbul's waterfront neighbourhoods (Lehtinen 2013). Massive population growth - together with rapid industrialization-has put increasing pressure on the Bosphorus. The main problem, however, is not the rubbish thrown in the Bosphorus, but the sewage water pumped into it. Almost all of biologically treated wastewaters having higher effluent quality are discharged to the Marmara Sea, whereas pretreated wastewaters are discharged to the Bosphorus strait (Baban et al. 2011).

The Golden Horn Estuary is a 7.5-km-long, 200- to 900-m-wide horn-shaped body of water that connects the Alibeykoy and Kagithane Rivers to the Bosphorus Strait. The Golden Horn Estuary supported thriving fisheries. From 1950s, unauthorized chaotic urbanization due to massive immigration, rapid and unregulated industrialization and inadequacy of sewage disposal resulted in thick layers of anoxic sediment, toxic bacteria, strong hydrogen sulphide odour and ecologically unliveable conditions (Perez et al. 2013; Coleman et al. 2009). The evidence of industrialization has been found in deep sediments of the Golden Horn, due to the poor circulation and massive contaminant absorption. For example, the two major sources of anthropogenic metals, especially zinc, copper and lead, were discharges from an iron and steel plant starting in 1948 and metalwork industries commissioned in 1959 (Coleman et al. 2009). In 1985, there were 700 industrial sites and 2000 businesses on the banks of the Golden Horn producing a smell that caused great discomfort to the people living in the area (Altinbilek 2006). The Istanbul Metropolitan Municipality and ISKI began a major environmental rehabilitation project in 1994. This rehabilitation project, which has been one of the world's largest estuary cleaning projects, has cost a total of US\$653 million. While once the biological life in the water of the Golden Horn was extinct, 33 different species of fishes are now observed in the estuary. The value of the coliform bacteria per $100 \mathrm{ml}$ is 1000 , while it was as much as 350,000 in 1998. The estuary is now open to swimming, rowing and navigation (Fig. 2). The Golden Horn Environmental Protection Project was awarded First Prize in the Metropolis Award in 2002 (Altinbilek 2006). 


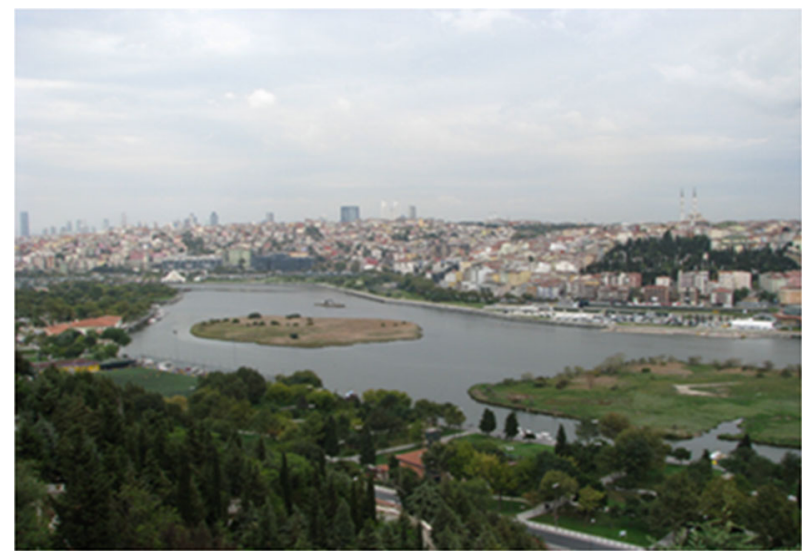

Fig. 2 Golden Horn, after its major clean-up (Photo by C. J. van Leeuwen)

The undertaken efforts were largely successful in revitalizing the area through dramatic water quality improvement. Consequently, the estuary is once again inhabitable for aquatic life as well as amenable to local resource users and foreign visitors, and Istanbul has regained a lost sense of cultural identity. The score for surface water quality, using national data for Turkey from the Environmental Performance Index (2010), is 5.8 (Table 4). However, water pollution in Istanbul and its reservoirs is still relevant (Saatci 2013), and a more realistic local score for surface water quality in Istanbul would be approximately 4 .

\subsection{Groundwater quality}

The bedrock of Istanbul consists of many types of rock: sandstone, limestone and quartz from Palaeozoic, Cenozoic age together with quaternary sediments. The Palaeozoic rocks consist of coastal shallow-marine clastics and carbonates, deep-marine shales and limestones and constitute the basement formation of the area. Groundwater quality, not in the area of Istanbul, but in the western European part of Turkey (Trace region), was studied by Özler and Aydin (2008). Chemical and microbial pollution was evident, and in some of the samples, the values exceeded the limits set by the European and Turkish drinking water directives. The high number of indicator microorganism which was present in the samples reflects the poor quality of water being used by these communities served by groundwater. Groundwater pollution in Turkey is caused by natural (salt water intrusion, geothermal water, discharges from contaminated lakes and streams and dissolution of minerals) and anthropogenic sources. The major anthropogenic sources are as follows: agricultural pesticides and fertilizers, mining waste products, industrial waste, on-site septic tank systems and pollution from poorly constructed wells (Baba and Tayfur 2011). In large cities, such as Istanbul, groundwater is also contaminated by leakage from sewers. Standardized information on groundwater quality is hardly available (Van Leeuwen 2013). Based on this scarce information, a provisional score of 4 has been assigned to groundwater quality in Istanbul.

\subsection{City Blueprint of Istanbul}

Cities vary considerably with regard to the sustainability of the IWRM (Van Leeuwen and Sjerps 2014). The variability has been captured in the Blue City Index ${ }^{\circledR}$. In 30 cities and 
regions reported so far, the BCI varied from 3.5 to 8.0 (Fig. 4). Cities with BCIs $>7.5$ are as follows: Amsterdam, Berlin, Hamburg and Malmö. Cities with BCIs lower than five are as follows: Kilamba Kiaxi (Angola), Belém (Brazil) and Dar es Salaam (Tanzania). Also Malta had a low BCI score. The final result of the City Blueprint analysis of Istanbul is shown in Fig. 3 and Table 4. The BCI of Istanbul is 5.3. This is an average score compared to the range of BCI values observed for the other cities and regions (Van Leeuwen and Sjerps 2014). This is shown in Fig. 4, where the BCIs of 30 cities and regions have been plotted against government effectiveness, one of the governance indicators of the World Bank (2012).

\section{Discussion}

\subsection{Methodological aspects}

The City Blueprint ${ }^{\circledR}$ is an effective and efficient manner to benchmark cities with regard to the sustainability assessment of their IWRM. The ultimate aim is to establish a network (learning alliance) of cities to share their best practices to improve the sustainability of IWRM in their city/municipality/region (European Commission 2014). These learning alliances are needed because the challenges in cities are important and urgent. Istanbul is no exception. The City Blueprint method is a baseline study and not a refined or comprehensive study on, e.g. asset management or water resources planning. Advantages and limitations of the baseline assessment approach have been discussed previously (Van Leeuwen et al. 2012; Van Leeuwen and Chandy 2013; Van Leeuwen 2013). To put the results for Istanbul in context, it is important to highlight these limitations of the City Blueprint approach:

1. The City Blueprint is a baseline assessment.

2. It is a snapshot or static picture. The City Blueprint does not provide a trend analysis.

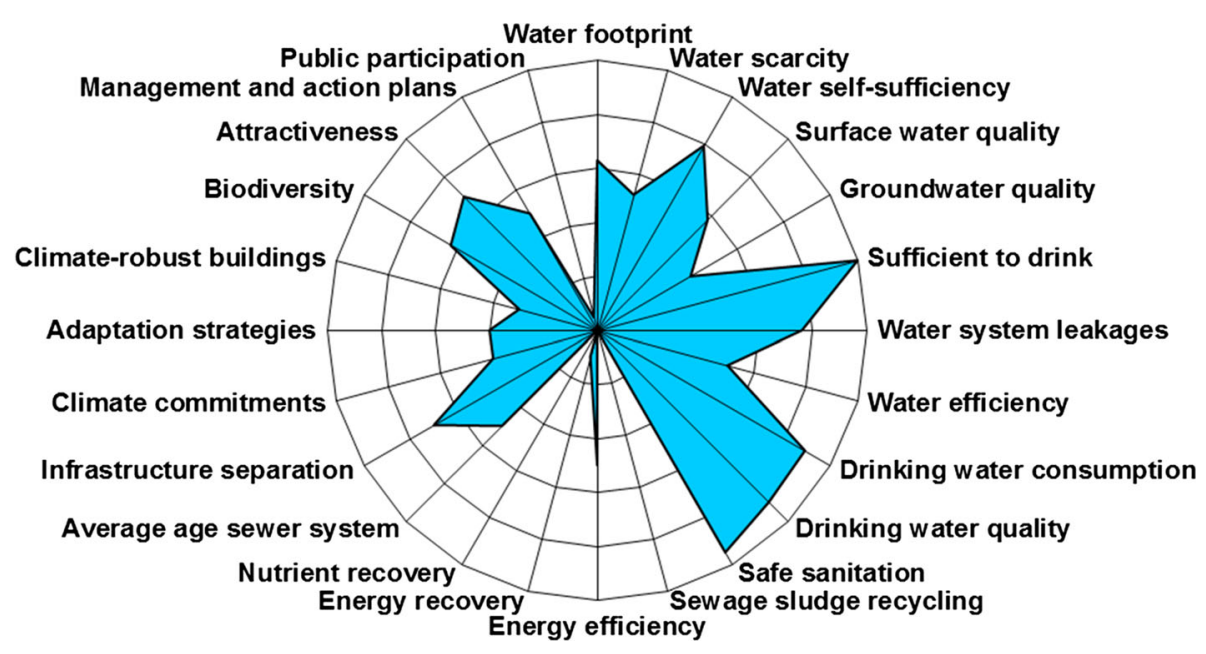

Fig. 3 City Blueprint of Istanbul. The BCI (Blue City Index) is 5.3 


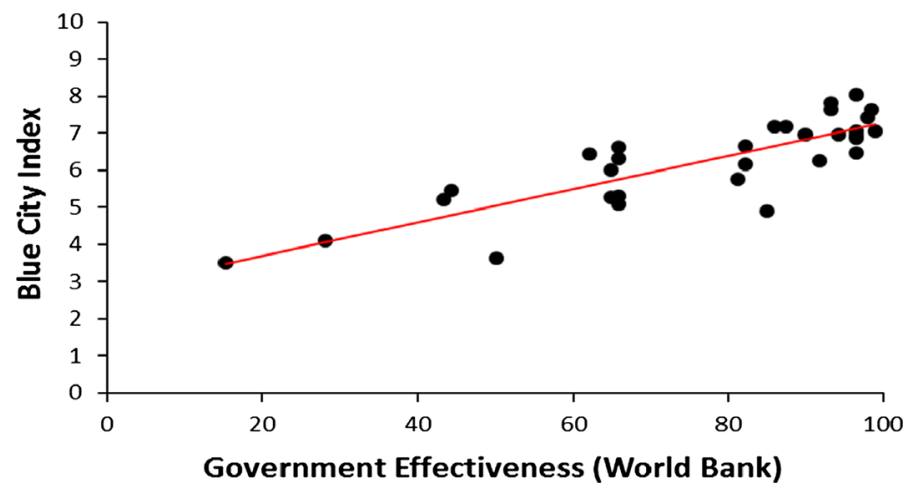

Fig. 4 Relation between the BCI and government effectiveness for 30 cities and regions

3. Local data are often not available for voluntary participation, surface water and groundwater quality, biodiversity of surface water and all water security parameters (Van Leeuwen 2013). The consequence is that estimates are made on the basis of regional/national data, and therefore, local environmental quality may actually be worse. Detailed information on the sources of information and the scoring is provided in the City Blueprint questionnaire (European Commision 2014)

4. Part of the scoring is subjective (e.g. attractiveness) and depends on stakeholder input.

5. The 24 indicators of the City Blueprint do not include economic indicators, but in the case of Istanbul a more extensive analysis has been carried out (see Table 3).

6. Care should be taken not to interpret the scores as the absolute truth. In fact, the discussion on the scoring of the City Blueprint with stakeholders shows that the City Blueprint is not so much a blueprint but more a discussion platform to start transitions, as shown in Fig. 1.

7. Indicators are not weighed, because the approach is a baseline assessment and the priority that can be attached to each of the indicators is per definition subjective (Van Leeuwen 2013). Furthermore, it is the responsibility of the local authorities and stakeholders to set priorities.

A major revision of the City Blueprint assessment framework will take place in the Horizon 2020 project BlueSCities (European Commission 2014), with the aim to include solid waste. The review is also carried out to provide a better separation between the local IWRM performances in cities and the 'context' of cities, i.e. the social, environmental and financial trends and pressures in countries. Istanbul will be one of the case studies in this project.

\subsection{Istanbul's future perspectives for water scarcity and droughts}

Based on the typology of cities as proposed by Van der Steen (2011), Istanbul can be categorized as a city with a moderate rainfall pattern, affected by climate change. The BCI of Istanbul is 5.3 and demonstrates that despite the enormous investments in IWRM of Istanbul, many aspects of Istanbul's water cycle can still be improved (Fig. 3; Table 4). This holds especially for sewage treatment ( $73 \%$ consists only of pre-treatment), sewage sludge recycling, energy recovery and nutrient recovery. Therefore, Istanbul can also be categorized as a city with potential for reuse of treated wastewater (Van der Steen 2011). 
The City Blueprint of Istanbul (Fig. 3) provides a static picture (a snapshot) of IWRM. To put the results in more perspective, future population growth in Istanbul, as well as water supply and demand information, needs to be considered, as well as climate change. It is estimated that the frequency of extreme events, such as droughts and intense rainfalls, will increase (Bekiroglu and Eker 2011; Patan 2012; EEA 2012). It is also expected that one of the main impacts of climate change will be water scarcity in the Mediterranean Region (Baban et al. 2011). Bekiroglu and Eker (2011) have studied drinking water supplydemand and deficit in Istanbul (Table 5) and demonstrated water shortages.

In a study of Baban et al. (2011), water demand did not exceed water supply. In recent years, Istanbul has been suffering from drought, especially in 2006, with the lowest rainfall being recorded in the last 50 years (Baban et al. 2011; ISKI 2013). ISKI, using a scenario of a $2{ }^{\circ} \mathrm{C}$ temperature increase by 2030 , estimated that the city's water supply may decline by as much as $14 \%$ over the next two decades because of higher evaporation from reservoirs. This is where habitat conservation comes in too. Bekiroglu and Eker (2011) correctly emphasize the importance of forested areas of Istanbul to drinking water supply, because most of the drinking water reservoirs are located in these areas. Recently, this has been highlighted in a short and impressive video as contribution to the fifth International Architecture Biennale Rotterdam (Kartaler 2012).

In addition to the water resources from the local reservoirs, water is transferred from the Melen Basin (180 km in eastern direction) with high costs. This project was set up to increase the water resources capacity and fulfil the increasing water of the region of Istanbul. The Melen project shall provide an annual volume of 1180 million $\mathrm{m}^{3}$ of water to fulfil the water requirement until 2040 (Patan 2012). In this way, the total water resources capacity of Istanbul will increase. As a result, the water shortage in Istanbul will be postponed for a while due to the new water resources constructed at high cost, but the need for more sustainable solutions remains crucial as one of the main impacts of climate change will be water scarcity in the Mediterranean Region. This is why ISKI explores other water resources for Istanbul (Patan 2012). These and other sustainable solutions, including water saving campaigns and reuse of treated wastewater, are under way (Baban et al. 2011; EEA 2012).

\subsection{Policy implications for IWRM and water governance}

IWRM requires integration at multiple levels, including those between the natural and social sciences, between scientists and managers, and between stakeholders and policy makers (Ison et al. 2011; Holzkaemper et al. 2012). Presenting information that is understandable to all parties can increase transparency and awareness, and this is an explicit goal of our City Blueprint assessment framework (Van Leeuwen 2013). IWRM is closely linked to ecosystem services as the sustainable allocation of water between agricultural, industrial and domestic use, and all other uses are a major challenge (Liu et al. 2013; Van Leeuwen et al. 2012). The ecosystem services approach is part of our City Blueprint approach (Van Leeuwen et al. 2012). Habitat conservation to protect these ecosystem services, as emphasized by Bekiroğlu and Eker (2011) and Kartaler (2012) for Istanbul, is crucial. In that respect, our case study of the megacity Istanbul demonstrates that water is one of society's critical assets and that major and urgent attention is needed to preserve these assets (Costanza et al. 1997; Hoekstra and Wiedmann 2014; Van Leeuwen 2013; World Economic Forum 2014).

An important conclusion from our previous work on 11 cities (Van Leeuwen 2013) is that the best performing cities (cities with a high BCI) are those with ambitions to make the 
urban water cycle more sustainable. These cities have an active population with a high Voluntary Participation Index (EFILWC 2006). Generally, these cities and regions are in countries with greater prosperity, i.e. a high GDP and high government effectiveness (Fig. 4). These conclusions were recently reconfirmed in our interim report for 30 cities (Van Leeuwen and Sjerps 2014).

According to the United Nations Development Programme (UNDP 2004), 'water governance encompasses the political, economic and social processes and institutions by which governments, civil society and the private sector make decisions about how best to use, develop and manage water resources'. The main obstacle for IWRM is adequate water governance. This has been highlighted in a report of the Organization for Economic Cooperation and Development where seven clear governance gaps have been described. This can provide a simple framework for cities to analyse these gaps and to improve their IWRM (OECD 2011). Recently, the UNDP has published a guidance document on water governance (UNDP 2013), which will be useful for cities too.

\subsection{The blueprint to safeguard Europe's water resources}

Freshwater constitutes only about $2 \%$ of the water on the planet, and competing demands may lead to an estimated $40 \%$ global water supply shortage by 2030 (2030 Water Resources Group 2009). The Blueprint to Safeguard Europe's Water is the European Union (EU) policy response to these challenges (European Commission 2012). It aims to ensure good quality water in sufficient quantities for all legitimate uses. Cities are concentrated centres of production, consumption and waste disposal that drive land change and a host of global environmental problems and are highly dependent on other cities and hinterlands to supply materials (including water), energy, and to dispose waste (Grimm et al. 2008; Bai 2007). Unfortunately, the blueprint to safeguard Europe's water resources fails to highlight the importance of cities as the challenges and solutions regarding sustainable water use will predominantly reside in cities and regions (European green city index 2009; Engel et al. 2011; UN 2012; UNEP 2012). Recently, the European Commision has implemented European Innovation Partnerships. EIPs aim to speed up innovations that contribute to solving societal challenges, enhance Europe's competitiveness and contribute to job creation and economic growth. EIPs help to pool expertise and resources by bringing together public and private actors at EU, national and regional level, combining supplyand demand-side measures. In 2013, the European Commision decided to set up an EIP on Water, and the City Blueprint Action Group on water governance has been one of the first action groups selected by the European Commission (2014).

\subsection{Europe's need for smarter cities and communities}

More than two-thirds of the European population lives in urban areas. Cities are places where both problems emerge and solutions are found (European Commission 2011). In order to develop sustainable cities, IWRM needs to be further integrated. According to the European Commission (2013), smart cities are cities that focus on ICT, energy and transport. Unfortunately, this policy currently excludes amongst other things, water, wastewater, solid waste, housing and climate change adaptation. According to the EIP Water City Blueprints Action Group, it is not coherent, but fragmented, and may lead to many missed opportunities for cities (European Commission 2014). With the urgency of the water governance crisis, it is time that we simply cannot afford to lose (2030 Water Resources Group 2009; Van Leeuwen 2013). The initiative of the European Commission 
on smart cities is welcomed, but needs to be transformed into a practical coherent longterm European Urban Agenda, e.g. an EUA-2050, with cities and based on the needs of cities. This is a top priority because an active civil society (with the inclusion of companies) is probably the most important driver for change towards sustainability in cities (EFILWC 2006; European green city index 2009; Fleming 2008). According to the City Blueprint Action Group, such an initiative may also lead to a better visibility and better image of Europe for the European citizens, which is a political priority for Europe after the 2014 elections for the European Parliament (European Commission 2014). An Urban Agenda with the focus on cities is even more needed in the rest of the world, where the challenges for IWRM are much greater and more urgent than for Europe (Dobbs et al. 2011, 2012). Thus, there is a need to move towards smarter cities:

1. Smarter cities are cities with a coherent long-term social, economic and ecological agenda,

2. Smarter cities are water-wise cities that integrate, amongst other things, water, wastewater, energy, solid waste, transport, ICT, climate adaptation and nature to create an attractive place to live

3. Smarter cities implement a circular economy (EMF 2014), focus on social innovation (Science Communication Unit 2014) and, last but not least, greatly improve on governance (OECD 2011).

Globally, we need regional platforms to exchange best practices between cities. The water sector is crucial but needs to reframe and to refocus radically (Van Leeuwen 2014).

\section{Conclusion}

The results of the baseline assessment of IWRM of Istanbul (Table 4; Fig. 3) confirm the conclusions provided in earlier studies (Altinbilek 2006; Uyguner 2009; Baban et al. 2011; Saatci 2013). Istanbul has set a good example to the challenges faced in water supply in megacities, where illegal settlements on watershed zones posed a threat to scarce water resources (Saatci 2013). Nevertheless, despite the enormous efforts of ISKI to provide adequate solutions for IWRM of Istanbul today, the projected future urbanization and population growth together with climate change will necessitate further major transitions towards a more sustainable IWRM for tomorrow. This holds for all aspects of the water cycle: water quality, water quantity, water supply and sanitation, coping with extreme weather events (flood and drought), as well as the protection of the sources of water, i.e. ecosystem conservation (OECD 2013; Bekiroğlu and Eker 2011). The time window available to do this is rapidly closing (2030 Water Resources Group 2009). These challenges for Istanbul are captured in an impressive video (Kartaler 2012). Our case study of IWRM in Istanbul confirms the conclusions of the World Economic Forum (2014) that water supply is one of the top three global risks for both the impact and likelihood.

In Europe, it is necessary that the European Commission takes the lead in the development of a practical coherent long-term European Urban Agenda, an EUA-2050, with cities and based on the needs of cities. Globally, we need regional platforms to exchange best practices between cities. The water sector is crucial but needs to reframe and to refocus radically (Van Leeuwen 2014). Fortunately, cities are not passively waiting but are already taking promising initiatives, e.g. by sharing their best practices and experiences (C40Cities 2014). 
Acknowledgments We would like to thank Dr. Mehmet Patan of Istanbul Water and Sewerage Administration (ISKI), Prof. Dr. Erdem Görgün of Istanbul Technical University and Dr. Aslihan Kerc of the Turkish Water Institute (SUEN) for providing information and feedback on earlier versions of this document. This work has been financed by KWR Watercycle Research Institute as part of its strategic research programme. It has been carried out in the context of Watershare ${ }^{\circledR}$ : sharing knowledge in the water sector (http://www.watershare.eu/) and is a contribution to the European Innovation Partnership on Water of the European Commission, and more specifically to the City Blueprint Action Group (European Commission 2014), coordinated by both Dr. Richard Elelman of Fundació CTM Centre Tecnològic and NETWERC H2O (Manresa, Spain) and Prof. Dr. Kees van Leeuwen of KWR Watercycle Research Institute.

Open Access This article is distributed under the terms of the Creative Commons Attribution License which permits any use, distribution, and reproduction in any medium, provided the original author(s) and the source are credited.

\section{References}

Altinbilek, D. (2006). Water management in Istanbul. International Journal of Water Resources Development, 22(2), 241-253. doi:10.1080/07900620600709563.

Baba, A., \& Tayfur, G. (2011). Groundwater contamination and its effect on health in Turkey. Environmental Monitoring and Assessment, 183(4), 77-94.

Baban, A., Goktas, O. C., Atasoy, E., Akalın, N. G., Donertas, A., Erdem, I. C., Magarzo, C., Hernández, M., Hocaoglu, S. M., \& Tobella, J. (2011). Integrated urban water management and investigation of new water resources. D5.1.1 conceptual scheme for rainwater harvesting and grey water management as alternative resource for Istanbul. D5.1.5a conceptual scheme of catchment and conservation of water from high flow events. Prepared 2011.020. Deliverable D5.1.1, D5.1.5a. http://www.prepared-fp7.eu/ viewer/file.aspx?fileinfoID=164. Accessed June 10, 2014.

Bai, X. (2007). Industrial ecology and the global impacts of cities. Journal of Industrial Ecology, 11, 1-6.

Baykal, B., Tanik, B. A., \& Gonecn, I. E. (2000). Water quality in drinking water reservoirs of a megacity, Istanbul. Environmental Management, 26(6), 607-614.

Bekiroğlu, S., \& Eker, O. (2011). The importance of forests in a sustainable supply of drinking water: Istanbul example. African Journal of Agricultural Research, 6(7), 1794-1801.

Brown, R. R., Keath, N., \& Wong, T. H. F. (2009). Urban water management in cities: Historical, current and future regimes. Water Science and Technology, 59, 847-855.

C40Cities (2014). Climate action in megacities. C40Cities Baseline and Opportunities. Volume $2.0 \mathrm{Fe}-$ bruary 2014. New York, USA.

Coleman, H. M., Kanat, G., \& Aydinol Turkdogan, F. I. (2009). Restoration of the Golden Horn Estuary (Halic). Water Research, 43(20), 4989-5003.

Costanza, R., d'Arge, R., de Groot, R., Farber, S., Grasso, M., Hannon, B., et al. (1997). The value of the world's ecosystem services and natural capital. Nature, 387, 253-260.

Dobbs, R., Remes, J., Manyika, J., Roxburgh, C., Smit, S., \& Schaer, F. (2012). Urban world: Cities and the rise of the consuming class. Washington, DC: McKinsey Global Institute.

Dobbs, R., Smit, S., Remes, J., Manyika, J., Roxburgh, C., \& Restrepo, A. (2011). Urban world: Mapping the economic power of cities. Washington, DC: McKinsey Global Institute.

EEA (2012). Urban adaptation to climate change in Europe: Challenges and opportunities for cities together with supportive national and European Policies. European Environment Agency. Copenhagen, Denmark: EEA Report 2/2012.

EFILWC. (2006). First European quality of life survey: Participation in civil society. Dublin: European Foundation for the Improvement of Living and Working Conditions.

EMF (2014). Towards the circular economy vol. 3: Accelerating the scale-up across global supply chains. http://www.ellenmacarthurfoundation.org/business/reports/ce2012. Accessed 2 June 2014).

Engel, K., Jokiel, D., Kraljevic, A., Geiger, M., \& Smith, K. (2011). Big cities. Big water. Big challenges. Koberich, Germany: Water in an urbanizing world. World Wildlife Fund.

Environmental Performance Index (2010). http://www.ciesin.columbia.edu/repository/epi/data/2010EPI_ country_profiles.pdf. Accessed 26 January 2015.

European Commission. (2011). Cities of tomorrow -challenges, visions, ways forward. Brussels, Belgium: Directorate General for Regional Policy. 
European Commission (2012). Communication from the commission to the European parliament, the council, the European economic and social committee and the committee of the regions. A blueprint to safeguard Europe's water resources. COM (2012)673 final.

European Commission. (2013). European innovation partnership on smart cities and communities. Brussels, Belgium: Strategic Implementation Plan.

European Commission (2014). European innovation partnership on water. City blueprints action group, Brussels, Belgium. http://www.eip-water.eu/working-groups/city-blueprints-improving-implementationcapacities-cities-and-regions-ag041. Accessed 30 June 2014.

European green city index. (2009). Assessing the environmental impact of Europe's major cities. Siemens, Germany: A research project conducted by the Economist Intelligence Unit.

FAO (2014). Aquastat: Global information system on water and agriculture. Food and Agricultural Organization of the United Nations http://www.fao.org/nr/water/aquastat/data/wrs/readPdf.html?f= TUR-WRS_eng.pdf. Accessed 25 January 2015.

Fleming, N. (2008). Understanding 'what's really going on' as a basis for transforming thinking, action and our cities. Paper presented at Enviro 08 Australasia’s Environmental \& Sustainability Conference \& Exhibition, Melbourne, Australia.

Grimm, N. B., Faeth, S. H., Golubiewski, N. E., Redman, C. L., Wu, J., Bai, X., \& Briggs, J. M. (2008). Global change and the ecology of cities. Science, 319(5864), 756-760.

Haci, M., \& Askin, G. (2008). Wastewater treatment systems in Istanbul and surroundings. Monitoring and modeling toxic and microbiological impact of wastewaters and rainwater discharges into the sea. Urban sanitation workshop. http://www.eau-seine-normandie.fr/fileadmin/mediatheque/Votre_agence_ de_leau/International/Atelier_assainissement/presentation_atelier2/Abstract_haci.pdf. Accessed 11 April 2013.

Hoekstra, A. Y., \& Wiedman, T. O. (2014). Humanity's unsustainable environmental footprint. Science, 344(6188), 1114-1117.

Holzkaemper, A., Kumar, V., Surridge, B. W. J., Paetzold, A., \& Lerner, D. N. (2012). Bringing diverse knowledge sources together-a meta-model for supporting integrated catchment management. Journal of Environmental Management, 96, 116-127.

Huynen, M. M. T. E., Martens, P., \& Akin, S.-M. (2013). Climate change: An amplifier of existing health risks in developing countries. Environment, Development and Sustainability, 15(6), 1425-1442.

IBNET (2013). The international benchmarking network for water and sanitation utilities. http://www.ibnet.org/en/production/?action=utility. Accessed 11 April 2013.

ISKI. (2013). Annual report 2012. Istanbul, Turkey: Istanbul Water Works and Sewerage Administration.

Ison, R., Collins, K., Colvin, J., Jiggins, J., Roggero, P. P., Seddaiu, G., et al. (2011). Sustainable catchment managing in a climate changing world: New integrative modalities for connecting policy maker, scientists and other stakeholders. Water Resources Management, 25, 3977-3992.

Kartaler, Y. (2012). Making a sustainable city. The Arnavutköy approach. The atelier Istanbul project. 5th International Architecture Biennale Rotterdam and Municipality of Arnavutköy, Istanbul. https:// vimeo.com/41973779. Accessed 11 April 2013.

Lehtinen, A. (2013). Cleaning up the Bosphorus. http://www.theecologist.org/News/news_analysis/ 1644701/cleaning_up_the_bosphorus.html. Accessed 11 April 2013).

Liu, S., Crossman, N. D., Nolan, M., \& Ghirmay, H. (2013). Bringing ecosystem services into integrated water resources management. Journal of Environmental Management, 129, 92-102.

OECD. (2011). Water governance in OECD countries: A multi-level approach. Paris, France: Organisation for Economic Cooperation and Development.

OECD. (2013). Water and climate change adaptation: Policies to navigate uncharted waters. Paris, France: OECD Studies on Water, OECD Publishing. Organisation for Economic Cooperation and Development.

Özler, H. M., \& Aydin, A. (2008). Hydrochemical and microbial quality of groundwater in West Thrace region of Turkey. Environmental Geology, 54, 355-363.

Patan, M. (2012). Water and waste water services in Istanbul. Istanbul water and sewerage Administration (ISKI). Presentation of 3 April 2012.

Perez, C., Ivanova, M., Antonova, P., Coman, C., Muhammetoğlu, H., Bat, L., \& Baki, O. G. (2013). Water quality management: Case study of Golden Horn (Halic)-Istanbul-Turkey. http://www.coastlearn.org/ water_quality_management/index.html. Accessed 11 May 2013.

Philip, R., Anton, B., \& van der Steen, P. (2011). SWITCH training kit. Integrated urban water management in the city of the future. Module 1. Strategic planning, ICLEI, Freiburg, Germany. http://www. switchtraining.eu/. Accessed 15 May 2013.

Saatci, A. M. (2013). Solving water problems of a metropolis. Journal of Water Resource and Protection, 5(4A), 7-10. 
Saatci, E., \& Akpinar, E. (2007). Assessing poverty and related factors in Turkey. Croatian Medical Journal, 48(5), 628-635.

Science Communication Unit (2014). Science for environment policy. In-depth Report: Social innovation and the environment. Report produced for the European commission DG environment, February 2014. University of the West of England, Bristol, UK.

Sen, Z. (2010). Investigation of effect of climate change on water resources of Istanbul and Turkey (in Turkish) http://www.ssfindex.com/cms/statplanet2012/indicator4-6/StatPlanet.html. Accessed 11 April 2013.

Tezer, A., Sen, O. L., Aksehirli, Cetin, N. I., \& Onur, A. C. T. (2012). Integrated planning for the resilience of urban riverine ecosystems: The Istanbul-Omerli watershed case. Ecohydrology \& Hydrobiology, 12(2), 153-163.

Turkish State Meteorological Service (2013). http://www.dmi.gov.tr/veridegerlendirme/il-ve-ilceleristatistik.aspx?m=ISTANBUL. Accessed 11 April 2013.

Turkish Statistical Institute (2013). http://www.turkstat.gov.tr/. Accessed 15 April 2013.

UN. (2012). World urbanization prospects: The 2011 revision. New York: United Nations.

UN. (2014). The United Nations world water development report. Water and energy (Vol. 1). New York: United Nations Development Programme.

UNDP. (2004). Water governance for poverty reduction. New York: United Nations Development Programme.

UNDP. (2013). User's guide on assessing water governance. Oslo, Norway: United Nations Development Programme.

UNEP. (2012). Fifth global environment outlook: Environment for the future we want. Geneva: United Nations Environment Programme Switzerland.

Uyguner, C. S. (2009). Vulnerability of the drinking water supplies of Istanbul metropolitan city: Current status and future prospects. Risk management of water supply and sanitation systems. NATO science for peace and security series C: Environmental security: 215-224. http://link.springer.com/chapter/10. 1007\%2F978-90-481-2365-0_20. Accessed 11 April 2013.

Van der Steen, P. (2011). Application of sustainability indicators within the framework of strategic planning for integrated urban water management. Sustainable water management in the city of the future. UNESCO-IHE Institute for water education. http://www.switchurbanwater.eu/outputs/pdfs/W1-1_ CALE_MAN_D1.1.7_Indicators_Manual.pdf. Accessed 7 January 2015.

Van Leeuwen, C. J. (2013). City Blueprints: Baseline assessment of sustainable water management in 11 cities of the future. Water Resources Management, 27, 5191-5206.

Van Leeuwen, K. (2014). Water in the city. Inauguration speech. University of Utrecht. Faculty geosciences. ISBN 9789062663583 (in Dutch).

Van Leeuwen, C. J., \& Chandy, P. C. (2013). The City Blueprint: Experiences with the implementation of 24 indicators to assess the sustainability of the urban water cycle. Water Science and Technology. Water Supply, 13(3), 769-781.

Van Leeuwen, C. J., Frijns, J., Van Wezel, A., \& Van De Ven, F. H. M. (2012). City Blueprints: 24 indicators to assess the sustainability of the urban water cycle. Water Resources Management, 26, 2177-2197.

Van Leeuwen, C. J. \& Sjerps, R. (2014). Water. City Blueprints ${ }^{\circledR}$ of 30 cities and regions. KWR watercycle research institute. Nieuwegein, The Netherlands. http://www.eip-water.eu/sites/default/files/EIPWater-City_Blueprints_Action_REPORT_June_2014_0.pdf. Accessed 11 July 2014.

Water Resources Group. (2009). Charting our water future. West Perth, USA: Economic framework to inform decisionmaking.

WaterWiki (2015). http://waterwiki.net/index.php?title=Facing_Water_Challenges_in_Istanbul. Accessed 2 February 2015.

WHO (2013). Progress on sanitation and drinking-water. 2013 update. World Health Organization. http:// www.wssinfo.org/fileadmin/user_upload/resources/JMPreport2013.pdf. Accessed 11 April 2013.

Wikipedia (2013). Water supply and sanitation in Istanbul. http://en.wikipedia.org/wiki/Water_supply_and_ sanitation_in_Istanbul. Accessed 15 April 2013.

World Bank (2012). Worldwide governance indicators. http://info.worldbank.org/governance/wgi/index. asp. Accessed 30 March 2014.

World Economic Forum. (2014). Global risks 2013 (9th ed.). Geneva, Switzerland: World Economic Forum. 